\title{
Changing Geopolitics and Negotiating Postures in the India-China Border Dispute
}

\author{
Zorawar DAULET SINGH \\ $\mathrm{PhD}$, Adjunct Fellow \\ Institute of Chinese Studies, 8/17, Sri Ram Road, Civil Lines, 110054, New Delhi, India \\ E-mail: zorawar.dauletsingh@gmail.com \\ ORCID: 0000-0003-0367-5743
}

\begin{abstract}
CITATION: Daulet Singh Z. (2021) Changing Geopolitics and Negotiating Postures in the India-China Border Dispute. Outlines of Global Transformations: Politics, Economics, Law, vol. 14, no 2, pp. 66-81. DOI: 10.23932/2542-0240-2021-14-2-4
\end{abstract}

\section{Received: 05.02.2021.}

\begin{abstract}
The article is based on the author's most recent book Powershift: India-China Relations in a Multipolar World (2020). It retraces the most salient moments and episodes in the India China border issue ever since the crisis broke out in 1959. What we learn from history is Chinese leaders have often shaped their policy on India as part of a wider geopolitical calculus, typically linked to the degree of pressure Chinese perceive on other geopolitical fronts. For India too, the nature of great powers relations impacts how it formulates China policy. This basic framework has remained relevant until the present day.

Over the past decade, as the world order began shifting to a multipolar balance of power, India and China have confronted challenges in their relationship. The relationship is at a crossroad, and both Del$h i$ and Beijing are struggling to find an equilibrium that allows both sides to pursue their interests and visions. Nevertheless, as Asia is returning to what it was for 1,800 years of the last two millennia, and, it is that big picture trend that Indian and Chinese leaders must pay attention to. Ultimately, this means stabilising India China relations
\end{abstract}

KEYWORDS: Indian foreign policy, Chinese foreign policy, India-China border dispute, multipolar world order, Deng Xiaoping

Although the border dispute with China is very old, Indian and Chinese leaders have yet to come to grips with how this issue can be resolved. The historical roots of the Sino-Indian frontiers have been narrated in several accounts since the 1960s. Understanding the historical variations and context around how China approaches the dispute has curiously received less attention. For, to make sense of the current scenario of India-China relations a focus on the intricacies of competing claims needs to be embedded in a geopolitical setting, which has been changing since the 1950s.

\section{China Links the Border Issue to its Geopolitical Environment}

Although the Chinese position provides the appearance of continuity, the actual bargaining posture has been one of extraordinary flux often shaped by geopolitical considerations that have little to do with the border itself. Let us explore each 
of these inflexion points in Chinas approach to the dispute.

In April 1960, Zhou Enlai embarked on an ambitious diplomatic mission to India to attempt a resolution. But let us recall the context. The previous year $\mathrm{Si}$ no-Soviet differences had come into view, ironically because Moscow publicly broke ranks with Beijing by taking a neutral position on the India-China dispute, and by the first half of 1960, Moscow had withdrawn its experts from China and suspended all economic contracts. 1959 had also witnessed two border skirmishes between India and China, including an especially nasty one in the western sector in Ladakh where nearly a dozen Indian security personnel were killed during a patrol in October 1959.

As consequence, the Chinese had come under pressure, particularly from the Soviets. In a rather heated conversation between Khrushchev and Mao shortly after that skirmish, the Soviets came down hard on the Chinese for escalating the dispute. ${ }^{1}$

<quote>Mao Zedong: "Nehru also says that the events in Tibet occurred on our fault. Besides, in the Soviet Union they published a TASS declaration on the issue of conflict with India."

N.S. Khrushchev: "Do you really want us to approve of your conflict with India? It would be stupid on our part."

N.S. Khrushchev: "...If you allow him (Dalai Lama) an opportunity to flee to India, then what has Nehru to do with it? We believe that the events in Tibet are the fault of the Communist Party of China, not Nehru's fault.'

(After an intense exchange, Mao placates the Soviets and promises a peaceful settlement.)
Mao Zedong: "You will see for yourselves later that the McMahon line with India will be maintained, and the border conflict with India will end...The border issue with India will be decided through negotiations." <quote>

It was in such a backdrop that Beijing made a decision in January 1960 to take a more pragmatic line on the dispute with India as well as other unresolved frontier disputes with neighboring countries. The PLA was also ordered to adopt a policy of restraint and avoid armed clashes. Mao sensed clearly that China was facing a difficult international environment and therefore decided to seek a negotiated settlement.

This basic sense of insecurity is reflected in a May 1959 Chinese note to India, which might have been personally drafted by Mao. ${ }^{2}$

<quote> "The enemy of the Chinese people lies in the east - the US imperialists have many military based in Taiwan, in South Korea, Japan and in the Philippines which are all directed against China. China's main attention and policy to struggle are directed to the east, to the west Pacific region, to the vicious and aggressive US imperialism, and not to India or any other country in the southeast Asia and South Asia....our principal enemy is US imperialism...China will not be so foolish as to antagonize India in the west.

Our Indian friends! What is your mind? Will you be agreeing to our thinking regarding the view that China can only concentrate its main attention eastward of China, but not south-westwards of China, nor is it necessary for it to do so. Friends! it seems to us that you too cannot have two fronts. Is it not so? If it is, here then lies the meeting point of our two sides. Will you please think it over?"<quote>

\footnotetext{
1 'Discussion between N.S. Khrushchev and Mao Zedong' on October 3, 1959, Cold War International History Project. Wilson Center Virtual Archive. Available at: https://digitalarchive.wilsoncenter.org/document/112088.pdf?v=401979fac3f7d5e1d51d0bcd3a80f4c5, accessed 10.03.2021.

2 White Paper 1 (1954 - August 1959). Notes, Memoranda and Letters Exchanged and Agreements signed between The Govern-
} ments of India and China. 
But Nehru felt this Chinese telegram had been "discourteous" and he rebuffed the implied suggestion to stabilize the crisis with China. Foreign Minister Chen Yi was equally candid when he shared Chinese threat perceptions to Swaran Singh in April 1960. Chen candidly admitted, "Our relations with the US and Japan in the east are tense. It would be stupid if we created a tense situation with India in the west also. The USA has its bases around us, atomic missiles and atomic weapons around us. Our dispute with India is very small...We are in a serious situation and need your friendship...The situation in the east being so tense we cannot afford to have trouble in the west also...If two ordinary countries are negotiating, they do not expose their difficulties to each other. (But) I am telling you about our difficulties... It would be best if we could reach some overall settlement, but if that is not possible some interim arrangement could be made." [Bhasin 2018, pp. 3278-3280].

Zhou's Delhi visit was an outcome of Beijing's policy to defuse tensions and arrest a worsening of its geopolitical environment. In his meeting with Nehru, Zhou Enlai explicitly offered that the line of actual control could form the basis of a settlement. But for India, how could there be any swapping of claims or "horse trading" as Nehru put it, if all the territory, whether Arunachal Pradesh in the east or Aksai Chin in the west, were Indian. India spurned overtures from China between 1959 and 1960 to reach an amicable settlement. More importantly, policymakers completely misread India's relative position in the changing international environment. This proved costly with India sleepwalking into conflict with a radicalized Mao in 1962. Even more consequentially, in early 1962 China and Pakistan began border talks and announced their agreement in December 1962. And thus, began the China-Pakistan strategic partnership.
On November 19, a day before the sudden Chinese ceasefire, Prime Minister Nehru in a famous cable prompted by a dire military collapse in the eastern sector, had practically invited President John F. Kennedy to intervene in the war. "The situation that had developed is, however, really desperate. We have to have more comprehensive assistance if the Chinese are to be prevented from taking over the whole of eastern India. Any delay in this assistance reaching us will result in nothing short of a catastrophe for our country." Nehru had requested for large scale US air support to the tune of 12 fighter squadrons, air defence systems manned by US personnel as well as two squadrons of deep strike bombers that would enable India to target Chinese air bases and communication lines inside Tibet [Bhasin 2018, pp. 4044-4046]. Washington's immediate reaction was to offer heavy lift capability to support Indian troop movements between sectors as well supply emergency requirements. But on Nehru's invitation for a more expansive US role in the resisting and pushing back the Chinese, the US was more circumspect. US thinking can be gauged in a November 19 cable from then US Secretary of State Dean Rusk to John Kenneth Galbraith, their ambassador in Delhi [Bhasin 2018, pp. 4049-4051]:

"This involves for us the most far reaching political and strategic issues and we are not at all convinced that Indians are prepared to face the situation in the same terms." Nehru's message was seen as not merely a proposal for a military alliance but complete commitment by US to the ongoing war. Rusk noted that the proposal "cannot be reconciled with any further pretense of non-alignment."

However, other geopolitical factors also played on US thinking. The US felt that active support to India might force the Soviets to support China. In fact, the Ken- 
nedy administration was beginning to debate options of adapting US's China policy. The key quid pro quo for Washington was that any US military assistance to India must be accompanied by Indian concessions to Pakistan. Rusk wrote, "To put in the most brutal terms, India now may face the choice between Pakistan assistance in the defense of India and some kind of satisfaction of Pakistan's interest in the Kashmir question." [Bhasin 2018, pp. 40504051]. Indeed, given the pressure from the US and UK, India would soon enter into several rounds of talks with Pakistan over finding some settlement in Kashmir. They ended in a stalemate because the Indian side, despite its weakness at the time, was determined not to part with any critical territory.

Nevertheless, Indo-US discussions during November 1962 did establish a basis for future cooperation. In July 1963, this was mutually expanded to include 'US assistance in strengthening India's air defenses' in the scenario of a Chinese 'attack on India'. Interestingly, during discussions to establish the terms of implementation of this July 1963 agreement, John Kenneth Galbraith 'was at great pains to stress that participation of the US Air Force in the joint training ... would not, by itself, imply any commitment on the part of the US Government to the defence of India.' Galbraith 'also made it quite clear that the agreement' regarding US consultations with India in the event of a Chinese Communist attack on India' would 'not commit the US to any particular action'. US response to a crisis would 'depend upon the situation at that time.' In the 1965 war, when India was poised to take the upper hand over Pakistan and China issued a threat and along with forward deploying its troops, India requested the US for consultations as part of the 1963 Air Defence agreement but was refused [Singh 2019].

On the whole, the 1962 conflict and its immediate aftermath convinced In- dia's policymakers that although they would need to adapt their foreign policy to draw more international support particularly for India's defense modernization, the cautious and transactional approach from the West including pressure being brought to bear on India's negotiating position on Kashmir as well as deep reluctance to confront China in the subcontinent strengthened the belief inside the Indian strategic establishment on the advantages of maintaining an independent foreign policy.

After the 1962 war, India and China would exist in a 'no war, no peace' type of relationship. Despite the 1967 Nathu La clashes, this phase would witness India asserting its position in the subcontinent by its performance in the 1965 and 1971 wars. Although India and China were in a state of a diplomatic freeze, China's domestic crises and simultaneous security challenges on its Russian and South East Asian frontiers made the India-China border relatively stable. The Himalayan border was largely unpatrolled - the Chinese had withdrawn to $20 \mathrm{~km}$ behind the LAC by 1963 and Indian forces too had pulled back. It was only in 1976 that the Indian cabinet took a decision to gradually resume patrolling on the LAC.

By the late 1960s, Prime Minister Indira Gandhi also signaled an adapted position on the border dispute. She decided to stop the publicizing of acrimonious demarches exchanged by both sides, as it "would cool tempers down" [Malhotra 2011]. In January 1969, the Indira Gandhi hinted in a press conference that India's position on the dispute and relationship could not remain static. She remarked that India would be prepared to explore ways of solving differences with China through talks that were not based on any preconditions. Even in Parliament, the government noted that it would like to "reduce tension" along the northern "frontier". 
After a hiatus of fifteen years diplomatic relations were re-established in 1976 when Indira Gandhi decided to exchange ambassadors. The process was carried forward in 1979 when Atal Bihari Vajpayee, as the foreign minister, visited China. From India's perspective, the visit was largely exploratory. Deng Xiaoping, unexpectedly, made a package proposal officially to Vajpayee without any prior diplomatic feelers. Deng told Vajpayee that a comprehensive settlement based on the exchange of claimed territories in the two sectors would settle matters for good. Deng ruled out a sector-by-sector approach $^{3}$ and used the expression "package solution", to describe his proposal, one that would settle the dispute in one go. In his memoirs, Foreign Minster Huang Hua records that the package offer was again repeated in his talks with India's Foreign Minister Narasimha Rao in June 1981. Sharada Prasad records that Deng Xiaoping repeated the "package deal" to Indira Gandhi's close advisor G. Parthasarathi in September 1982. Unfortunately, India was unable to even accept the swap principle let alone endorse it as the basis for a border settlement.

Let us, again, explore the geopolitical context underlying China's postures. While the ice had been broken in Sino-American ties in 1971, the normalization process assumed a greater impetus after Mao's demise and the arrival of a reformist Deng Xiaoping. A month before Vajpayee's February 1979 visit, Deng was in Washington engaging in candid exchanges with the Carter administration on countering the "Polar Bear". Both sides were quite explicit that Sino-American geostrategy must seek to wean India away from its Soviet ally. US national security advisor, Zbigniew Brzezinski told Deng, "The US has improved its relations with India" and "it's important for Sino-Indian relations to improve as well". Deng "agreed" with this logic. On Pakistan, Deng urged Carter to provide "solid assistance".

Recall that Zhou Enlai's swap offer of April 1960 had emerged after the heated Khrushchev-Mao meeting in October 1959 when Soviets advised the Chinese to de-escalate and peacefully settle their problems with India. In 1979, the Chinese were now in the US camp and Deng's offer was part of the coordinated anti-Soviet containment posture adopted by China at the time, part of which was to pull India towards the US and Chinese side in the Cold War. Indian policymakers were generally conscious of Chinese motivations. As one note from 1976 conjectured, one of the reasons for China may be "the hope of detaching us from the USSR, or even turning us against her?" If so, we cannot oblige them. They seem to have greater hopes of influencing India..."4

In January 1980, Deng Xiaoping told visiting US Defense Secretary, Harold Brown that "after Pakistan has been strengthened, India will become a more stabilizing factor" in South Asia. Brown's comments to Chinese Vice-Premier Geng Biao are instructive: "Indians must be brought to realize that there is no longer a concern about a threat from China. We think it is important that you renew a dialogue with the new Indian government and seek a compromise understanding on the border issue that would permit India to turn its attention elsewhere." China's attempted rapprochement with India must be located in the wider geopolitics of the time as US and China sought to pull India

\footnotetext{
3 Vajpayee had expressed the Indian position that it should be possible to deal with areas of little or no difference first (the eastern sector) and then move on to areas where there was greater divergence (Aksai Chin).

4 National Archives of India (NAl) - Box File 2: Folder title: HI/103/7/76.
} 
away from the Soviets and isolate Moscow in South Asia.

So, China continued to repeat its swap offer in 1980, 1981, 1982 and continued to privately mention it until 1984 . Indira Gandhi was interested in exploring such a deal but then apparently changed her mind at the last minute. Formal border talks were established after foreign minister Huang Hua's visit to Delhi in June 1981. Eight rounds of talks were held between December 1981 and 1988. During the initial rounds, both sides adhered to their bargaining playbooks: India sought to address the eastern sector first which it viewed as relatively solvable and hoped to create a positive atmosphere for discussions on the western sector. China favoured a "comprehensive settlement". Then, in the sixth round in November 1985, Chinese negotiators pressed claims in the eastern sector south of the McMahon Line. In an interview to Indian journalists in June 1986, China's Vice Foreign Minister, Liu Shuqing, said "the eastern sector is the biggest dispute and key to the overall situation". The official Chinese statement after the seventh round in July 1986 stated, "The Indian side noted a hardening of the Chinese stand...”.

Again, the changing geopolitical environment might explain the shift in Beijing's approach. By 1983, China was once again beginning to rebalance its foreign policy towards non-alignment after problems over Taiwan resurfaced in US-China relations. For its part, Moscow was attempting its own rapprochement with the post-Maoist leadership and offered to reopen border talks in February 1982. The post-Brezhnev Soviet leadership continued its China outreach with Huang Hua visiting Moscow in November 1982. Finally, in July 1986, Gorbachev sought to structurally transform the Sino-Soviet relationship and pave the way for a normalization process culminating in Gorbachev's 1989 China visit. During Gorbachev's India vis- it in November 1988, "The Soviets made it clear that they wanted to normalize their relations with China, and called upon India to do likewise." With Moscow assuming a neutral position on the India-China dispute, the impact on China's calculus was clear: it no longer felt the need to win India over to its side. By the time of the Rajiv Gandhi-Deng Xiaoping December 1988 summit, India's global geopolitical position had actually weakened with China no longer perceiving India through a triangular Sino-Soviet lens. Incidentally, the US through a backchannel had encouraged Rajiv Gandhi that Deng Xiaoping would reciprocate his overtures.

The new geopolitical context after 1991 would prompt Delhi and Beijing to further stabilise their relationship and the border. The uncertainty and shared anxieties towards a new unipolar world along with domestic changes in India and China as both countries sought to promote economic reforms and domestic stability, it would bring both to entertain a rapprochement. A major agreement in 1993 would de-link a settlement of the boundary "from the maintenance of peace on the border" with both sides also formally renouncing "the use of force to settle the issue." [Menon 2016, pp. 26-27].

What drove this shift? It is apparent that both sides had their backs to the wall during the early post-Cold War years. With China was still under the scanner for its human rights record, and India too confronting major externally fueled insurgencies in Punjab and Kashmir, both countries were able to normalize ties as well as craft substantive norms to stabilise the LAC. Reciprocating India's non-interference during the 1989 Tiananmen crisis, China also did not interfere in the escalating crisis in Kashmir during the early 1990s. Even during the Kargil conflict later that decade, Chinese called for the removal of Pakistani troops to their pre-conflict positions as part of ending the war. 
The next big move came in April 2005 during Wen Jiabao's India visit. India and China signed a 'Political Parameters and Guiding Principles' Agreement, which constitutes a set of principles that finally reconciled hitherto competing positions, and importantly, albeit indirectly, implied a path to return towards a comprehensive swap deal with minor exchange of territory. Yet again, changing geopolitics appeared to be the underlying factor behind Beijing's surprising decision to formally endorse such an agreement. A new American policy to normalize the relationship with India and locate it in a wider Asian geopolitical setting may have prompted Beijing to raise its own game with India via the 2005 agreement. The follow through, however, quickly fizzled out for reasons that remain unclear. It has been suggested that Beijing was probing India's new orientation and the intentions of India's new strategic partners. Nevertheless, China shifted towards a passive-aggressive policy of simultaneous engagement and a gradual "hardening" of their stand on the border dispute. For the past decade, this has been the general pattern of ties with engagement punctuated by a series of border crises and standoffs.

\section{Will We See Another "Swap Offer"?}

We are now at yet another global inflexion point with a changing Chinese posture. US and China appear to be on a path of heightened international competition. The alignment with Russia has given China enhanced strategic depth to re-define its role and assume more great power characteristics than it could do alone. It is reasonable to postulate that China's geostrategy would prefer a cooperative India and stable Himalayan frontiers. But to what extent this would shape China's incentives to solve the dispute on reasona- ble terms remains unclear. After all, China is nowhere near as isolated, vulnerable or domestically divided as it was in previous episodes when a border resolution was viewed in Beijing as a positive lever to stabilize its southwestern periphery. China's deep economic interdependence with its neighbours and relatively swift recovery from the Covid-19 crisis is in sharp contrast to periods of greater domestic instability such as the late 1950 s, late 1970 s or the late 1980s. The power asymmetry with India is also wider than it was in those previous decades, again reducing the necessity for China to make concessions to buy India's cooperation. In fact, the recent 2020 Ladakh crisis has revealed that China can entertain more coercive and unilateral options to secure its security and territorial interests on the border with India.

The Indian elite for its part must enlighten the body politic that its original claims to Aksai Chin are not cast in stone and were too casually inserted into the border narrative and official negotiating position with consequences that are still with us. But India must also cast its gaze on global geopolitics and discern changing trends with a sober outlook and always with an eye on its own long-term interests. It would be a premature and even dangerous premise to visualise that India's relative global position enables it to actively play triangular or quadrilateral geopolitics with China. To 'swing' towards an anti-Chinese alignment and hope to be 'weaned away' by China is unlikely to work in practice. In fact, since 2015, this geostrategy has largely failed to produce the envisaged gains. A key reason and one that continues to elude many Indian geostrategists is China's negative or coercive leverage on India - both vis-à-vis Pakistan and structural superiority on the Himalayan frontiers - cannot be offset by an external balancer. Further, the so-called balancing partner, the US actually finds itself closer to China than India when it comes to Pakistan's domes- 
tic affairs and the basic balance of power and strategic stability in the subcontinent. Furthermore, the main threats that the US seeks to prepare for with respect to China are all in the Western Pacific, a large distance away from the India-China border.

Bluntly put, it would be illogical for India to open a Cold War-style front with China when the potential costs would significantly outweigh the geopolitical gains. A more prudent course would be to maintain the present multi-directional engagement with China and its neighbours, and, simultaneously more intelligently on buttressing the domestic sinews of India's comprehensive national power along with elevating its status in the neighborhood by a more enlightened regional policy. That alone will gradually transform the regional environment and alter Chinese incentives to cultivate a serious and strategic equation with India.

The next opportunity for a border settlement will probably emerge as unexpectedly as they did during the previous episodes. If history teaches us one insight it is that opportunities to solve this question last for brief windows before the cycles of uncertainty rear their impact on India-China relations. It would require bold leadership and geopolitical acumen to convert fleeting moments into an enduring settlement.

\section{A Multipolar World Order}

Dizzying changes in Asia and the world, a Himalayan border crisis with military casualties for the first time in 45 years, globalization under deep stress, an America that is unable to resolve its domestic fissures and craft a new international role, are together changing the context for India-China relations. The conundrum which surrounds China's rise has led to a debate that is long on rhetoric and short of realistic ideas for India's foreign policy.
History might provide some lessons and clues since the cycles of competition and acrimony have played out previously when new global powers have emerged and erstwhile ones have declined.

Looking back at the outbreak of the first Cold War in the late 1940s and early 1950s, the world witnessed an even more dramatic change in the balance of power. The post-Second World War order in Asia was one of multiple power transitions: a decolonization process that from the perspective of the West was fairly disruptive and a strategic set back to their centuries long dominance in Asia, China's return to the international mainstream after their century of humiliation in 1949, Indias return to the world stage in 1947 after a prolonged period of colonialism. In a sense, we have been dealing with major changes in the vast Indo-Pacific region for a long time. The challenges India faces on the Himalayan frontiers are also not new. The 1950s witnessed a destabilized periphery as China sought to aggressively restore its presence and authority over Tibet after a long period where the British had diminished Beijing's influence in Lhasa and altered the geopolitics of the Himalayan areas in favour of British India.

It is always disconcerting to see India's strategic discourse mystify China. After all, we have been living with the PRC as a neighbour for 70 years and the fact that we are constantly trying to reinvent the wheel is something that needs to be set aside. The policymakers during the Cold War were quick to recognize that dealing with China requires a framework that is tailored to Indias circumstances. This means an advantageous realpolitik where India leverages the international environment to augment its power potential and cultivate a network of partners. It also implies a sophisticated understanding of what it means to live in a common Asian and South Asian neighbourhood with overlapping peripheries extending to thousands of kilometres. In- 
dia has struggled to find that equilibrium between shaping not only a balance of power but also a balance of interests. The emerging multipolar world order will call upon Indian leaders to strike that balance.

Reflecting on how India dealt with China during the Cold War might provide some lessons. Delhi had developed fairly positive ties with Washington and Moscow and was able to draw on economic and military assistance because both those superpowers, in their own strategic calculations, sought a balance of power in Asia and did not wish to see Chinese hegemony extend all the way into Southern and Southeastern Asia. Thus, there was a natural convergence between India and the superpowers and how they looked at China's future in the vast region. That basic convergence continues to exist even today. This is despite a Russia-China partnership that seeks to counteract some of the unilateralist impulses of the US and despite a massive $\$ 700$ billion commercial relationship between the US and China.

It is surprising when observers talk of India's reticence or timidity in developing strategic partnerships. Take, for example, the India-US relationship after 2005 that has seen a sustained evolution towards a similar outlook on shaping Asia's balance of power. It has not been a smooth ride nor has it culminated in (or will ever) total convergence. But there is a basic understanding between the two countries. Similarly, with Russia too we have seen a high level of military assistance, high technology support, and the more recent Indian initiatives to dovetail Russia's eastern pivot with India's 'Act East' policy towards the Arctic and Northeast Asia. Also noteworthy are India's attempts at persuading Moscow to assume a deeper role in the Indian Ocean. With Japan and Vietnam too, India has similar motives of driving cooperation. In sum, India has been consistently seeking to establish common ground with other players on China's periphery who are also looking out to where China is headed in the next 15-20 years, taking into consideration simply the sheer size of its future power.

The problem really arises about the avenues for India to convert that convergence and gain leverage vis-à-vis China in an operational sense whereby Beijing adjusts its policies. For the last decade-anda-half, India has been pursuing a very similar approach where it is trying to deepen ties with China's other neighbours and the major powers with an aim to unsettle the Chinese into making a deeper outreach to India in terms of both engagement and perhaps even some concessions on certain fronts. But that has not entirely played out as Indian strategists would have hoped and the primary reason is that the asymmetry of comprehensive national power between India and China is far higher - indeed it widened during this phase - than it was during the first Cold War. The aspects that Indian policymakers might believe would serve as a pressure point on China do not appear significant enough for Beijing to make that adjustment or accommodate India's preferred position that it would like to hold in Asia and the subcontinent.

One can discern a Chinese approach to South Asia, which is remarkable for its conservative consistency and the way Beijing defines its interests in the region. The approach has four pillars - maintain some sort of balance between India and Pakistan; ensure that India does not create trouble in Tibet; develop political and economic ties with all South Asian states including India; prevent South Asia from falling into a US sphere of influence and thereby pose a major regional challenge to China's southwestern periphery. While in practice, India's place and status has increased in this overall framework, especially over the past two decades, the overall Chinese approach is still driven by counteracting any adverse 
spillover effects on Chinese security interests on its periphery rather than a dynamic and sophisticated strategy of crafting a wider political equation with India.

This is not to say that Chinese policymakers are unmoved by India's rise. Debates in China in the last few years do suggest that India is being looked at more seriously. The Chinese are looking at their southwestern periphery and South Asia from a perspective where India can no longer be ignored. Some also see India as a spoiler and an irritant that can undermine Chinese interests and ambitions. The dominant view is that "India has to be kept under control." ${ }^{5}$ Other than lofty rhetoric, however, we have not seen a sophisticated approach from China to reach out to India and attempt a new modus vivendi. The Chinese still assume a position of safeguarding their narrow strategic interests and zones of concern and hope to slot India into that geopolitical map, and if unsuccessful then work around it.

Is China being short-sighted in not adjusting to India's rise, even though the power asymmetry might not require it to do so today? There is merit in this argument. After all, with a 5-1 advantage in economic power and perhaps even greater, when measured in a qualitative sense of high technology and available pool of human and scientific capital, there is no historical precedence for an accommodation between a major power (China) and a rising power (India) under such apparent circumstances of an asymmetry. Yet, what if China were to take a position that India is going to be a major player in southern Asia and the northern Indian Ocean and more gradually in the Asian geo-economic space over the next several decades? If Chinese leaders and thinkers were to adopt such an outlook on India's future, then they should logically consider investing in the anticipation of India's rise and making some adjustments to accommodate Indian concerns and aspirations. Why has China not been able to visualize such a framework? Is it because they are deeply invested in Pakistan? Is it inertia? Is it an unwillingness to accept the risk of getting it wrong?

While the Chinese have kept their cards close to their chest, some of these dilemmas are reflected in their debates. It does appear that they are not able to justify making these geopolitical investments because they feel no matter what they do, in their perception China will never be able to ever cultivate an India that is going to move away from the west and towards them. As one Chinese scholar puts it, 'From the foreign policy of the Indian government it is now very clear that India has decided to stand with the US in the great power competition.' ${ }^{6}$ Yan Xuetong, a leading Chinese scholar, recently remarked, "the view in Chinese eyes is the current government in India has given up non-alignment and has a motivation to become a US ally, using non-alignment as a cover to make policy." [Banik 2020]. Some Chinese strategists also "see India enticed, entangled, and potentially enmeshed in institutionalized (US-led) cooperative frameworks that it later cannot reject despite its aspiration for autonomy." [Sun 2020].

Whether such assessments reflect reality is less important because perceptions are what ultimately shape high policy and India needs to take it seriously. Then

5 Suhasini Haidar (2020) LAC Face-off | Doklam Was a Game-changer for Chinese thought on India: JNU Professor Hemant Adlakha. The Hindu, July 4, 2020. Available at: https://www.thehindu.com/news/national/lac-face-off-doklam-was-a-game-changer-for-chinese-thought-on-india-scholar/article31989759.ece, accessed 10.03.2021.

6 Singh A.Gh. (2020) What Strategic Experts from the Other Side Think about Ladakh Standoff. India Today, September 4, 2020. Available at: https://www.indiatoday.in/news-analysis/story/india-china-what-strategic-experts-from-other-side-think-about-ladakh-standoff-1718661-2020-09-04, accessed 10.03.2021. 
'there's also a psychology in China...that if China makes a concession to India, because India is now in a better (geopolitical) position, the Chinese concession will not be interpreted as Chinese goodwill. It will only be interpreted as a result of India's improved strengths. (And) by that logic, India is going to make demands for more concessions, and instead of reciprocating to what the Chinese would deliver.' [Swami 2020]. Another scholar, Yun Sun summarizes the key problem obstructing a geopolitical accommodation, 'Key concessions India demands from China on the border settlement are hard commitments that cannot be reversed. By contrast, what China seeks from India, such as its neutrality in the US-Chinese strategic competition, is ephemeral and easily adjustable.' [Sun 2020]. This problem of uncertainty and fluidity in strategic intentions has no apparent solution for the forseeable future. Neither are the Chinese persuaded that India will defy its own uneven track record and undertake a domestic transformation like conventional great powers in history. This belief, again, reduces China's incentives for an early modus vivendi.

That being said, China does find strategic value in seeing an India that has strategic autonomy and 'does not in any way influence or jeopardize the larger and crucial strategic ongoing struggle with the US.7 It is worth recalling that the so-called $2018 \mathrm{Wu}$ han reset was predicated on an Indian reassurance to China that Delhi would maintain its independence - 'strategic and decisional autonomy' - in a changing global environment. ${ }^{8}$ What can be discerned from Chinese public debates is the recognition that the relationship with India can no longer be handled by simply ignoring it.
The debate really is about the means there is disagreement between Chinese strategists and scholars on how to attain a more manageable periphery and stable relationship with a large neighbour like India. Some advocate an uncompromising policy of pushing back because India's friendship and cooperation can never be obtained; others advocate a more sophisticated approach where China does not lose sight of its primary direction of threat in the Western Pacific emanating from the US, and therefore urge dealing with India in a way that supports its strategic autonomy and does not feed into US grand strategic goals. As one Chinese specialist on South Asia candidly observes, 'If India chose to balance China in the region through a "soft alliance" with the United States, China will likely respond by increasing its influence with other states in the region to hedge India's leadership. But if India proceeds more cautiously regarding American cooperation, mutual learning will be easier.' [Xiaoping 2018].

China's India policy debate will not be settled any time soon, just as India's debates that weigh the maintenance of an independent foreign policy with the alternative option of a pro-US tilt and participation in a military structure with the US and its allies. So, both Delhi and Beijing are weighing different options to shape the balance of power and while simultaneously preventing it from deteriorating. What we have not seen enough of is an approach that provides a framework for a balance of interests. This is something of a puzzle. If there is one common theme in Indian and Chinese debates it is both sides recognise the adverse impact of a destabilized overlapping periphery or a broader Cold War-

\footnotetext{
7 Suhasini Haidar (2020) LAC Face-off | Doklam Was a Game-changer for Chinese thought on India: JNU Professor Hemant Adlakha. The Hindu, July 4, 2020. Available at: https://www.thehindu.com/news/national/lac-face-off-doklam-was-a-game-changer-for-chinese-thought-on-india-scholar/article31989759.ece, accessed 10.03.2021.

8 India-China Informal Summit at Wuhan (2018). The Ministry of External Affairs, April 28, 2018. Available at: https://mea.gov.in/ press-releases.htm?dtl/29853/IndiaChina_Informal_Summit_at_Wuhan, accessed 10.03.2021.
} 
style rivalry in the region. The way out China needs to adjust to India's rise and sensitivities, while India needs to recognize China's primary direction of threat lies in the east.

Deng Xiaoping once advised the Chinese people, 'The role we play in international affairs is determined by the extent of our economic growth. If our country becomes more developed and prosperous, we will be in a position to play a greater role in international affairs.' India's leaders would do well to remember this dictum. The sinews of power are inextricably linked to a strong and balanced economy. During its domestic transformation a process likely to last for the next several decades - it is in India's national interest to have a degree of competitive, but peaceful, co-existence with China. The only realistic way to cultivate such a stable relationship with China - and history underscores this - is when both legs of a policy framework operate in tandem. One is having a balance of power policy, that is, stable ties with the major powers including avoiding getting entrapped in their power plays with China and on the other hand, having a very sustained policy of engagement with China. This does not mean merely a flurry of summitry between the leaderships or public diplomacy but developing a complex interdependence through people-to-people, commercial and cultural connections - a meaningful dialogue on regional security (without, of course, yielding on any core interests), and more creative collaboration in safeguarding and reforming the next chapter of globalization so the interests of large developing economies are secured in a multipolar world. This is not dissimilar to the strategic approach adopted by the US and Russia in their management of China's rise.

In the immediate South Asian region too, India needs to choose how it wants to stabilize the Himalayan neighbourhood sandwiched between India and China, define what kind of space it sees in the subcontinent for China and then mobilize national resources to manage China's footprint. A regional framework for China has not really been conceived in India. Delhi has mostly been reacting to and catching up with what is a recent phenomenon China's growing geoeconomic footprint in South Asia is barely a decade old. During this brief period, China has established a position - with the cooperation and invitation of regional political and economic elites - that is not easy to dislodge. India's challenge is to shape the future of China-South Asia ties in a constructive direction where Delhi can get the neighbourhood on board to support at least certain core fundamentals norms. It is a challenge of strategy but also one of re-defining India's regional role more intelligently.

On the economy, the debate over the extent of cooperation with China has evoked much controversy, partly triggered by the 2020 border crisis but also in the backdrop of India seeking to promote large Indian business houses and domestic industry, many of whom find Chinese competition overbearing. The politics surrounding the US-China trade conflict has also influenced Indian policymakers in attempting something similar for India-China relations. Decoupling, however, should not be pursued until a deeper assessment is undertaken to determine the cost-benefit calculations and impact, across sectors, and for the economy as a whole. Only after this has yielded credible data should policymakers formulate a plan to develop more interdependence with China in select sectors or lessen it in others by import-substitution and sourcing from elsewhere. It must not be a blanket policy, nor motivated by ideological considerations. We first need to articulate a sophisticated industrialization blueprint and identify where Beijing and other major econo- 
mies bring value or can be a catalyst in the way the US was for China's reform process.

The US-China competition over high technology, particularly in digital sectors, is posing another policy challenge. Here, India's policymakers need to avoid leaping from one digital superpower to another. After all, both Chinese and US companies bring the same baggage to the table - the risk of compromising data sovereignty and privacy, dependence on imported software and hardware, and impact on domestic capabilities. Before handing over the family silver, India needs to support a framework for domestic innovation that promotes a competitive digital ecosystem and one that moves India up the value chain. More broadly, India's policymakers should recognize that China and East Asia's innovation and technological transformations occurred by strategically leveraging interdependence with major economies and not building walls.

As the debate rages on in the bilateral dimension, India's policymakers should keep an eye on India's quest to deepen economic ties with Asia more broadly. If you look at the Indo-Pacific geoeconomic space, the preceding decades have created a political economy of deep trade and investment linkages between China and its neighbours - from Western Europe, the heart of Eurasia to Northeast Asia, Korea, Japan, Australia, ASEAN. This is an extensive economic space that is likely to evolve further as more integration processes and connectivity linkages develop in the coming decade. The question for India should be how it wants to fit into that emerging geoeconomic community. One cannot fit into the Asian economy by completely sealing off China from the Indian economy. This is because China is going to be involved in some way or the other with all major Asian economic centres - China is already the biggest commercial partner for all its neighbours - which include India's strategic partners. A prudent course would be to identify the sectors and technological areas in which India wants to engage with China, because its integration with Asia is at another level linked with that choice and strategy.

Finally, what can we discern through the haze in the post-Covid world? One probable scenario is if the US fails to get its act together at home, China's linkages with other major economies of Asia would deepen. India might find itself with an uphill task upon re-entering that space in a decade from now because of its choice to step back from trading arrangements such as the Regional Comprehensive Economic Partnership (RCEP) ostensibly to industrialize and regenerate - captured in the phrase, 'Atmanirbhar Bharat' - its domestic industry and innovation ecosystem. The Asia of 2030 will look very different from the Asia of today and will most likely be an amplified version of the interdependence that has already been established over decades. For the first time in several centuries, we are facing the prospect of an Asia that can actually flourish on its own economically, and not simply by playing a role as an assembly-hub and export powerhouse to the West. Greater Eurasia has the energy resources and strategic commodities of Russia including its strong scientific base of human capital, as well as the commercial technologies of Japan, China and Korea. It also has the human capital and the demography to maintain a self-sustaining political economy.

In essence, Asia is returning to what it was for 1,800 years of the last two millennia, and, it is that big picture trend that India needs to pay attention to. While the West will remain important, there is no viable way for India to avoid being part of this dynamic Asia and Greater Eurasia. Eventually, that boils down to having some sort of a stable India-China relationship. It has, thus, fallen upon the present generation of policymakers to steer India towards this complex multipolar world order. Ma- 
jor strategic choices have to be made and one hopes that India's leaders have the long-term view.

The historian Odd Arne Westad recently remarked, 'The more the US and China beat each other up, the more room for maneuver other powers will have.' One should equally apply that mantra to India and China. Unrestrained competition only benefits other powers. As the 2020 Lada$\mathrm{kh}$ crisis bookends a tumultuous decade of India-China relations, both Delhi and Beijing would do well to heed the call of our time. History is obliging both countries to step up and play constructive roles to shape the emerging world order even as it is impelling both sides to learn to co-exist in a common neighbourhood.

\section{References}

Banik A. (2020) Implications of China-US Competition in the Digital Age: Webinar of Dr. Yan Xuetong. Institute of Chinese Studies, September 18, 2020. Available at: https://www.icsin.org/uploads/ 2020/09/23/c973369f98f0f1dc2e373c6e6deff0f6.pdf, accessed 10.03.2021.

Bhasin A.S. (2018) India-China Relations 1947-2000: A Documentary Study (Vol. 4), Delhi: Geetika Publishers.

Malhotra I. (2011) The Colombo 'Compromise'. The Indian Express, October 17,
2011. Available at: https://indianexpress. com/article/opinion/columns/the-colombo-compromise/, accessed 10.03.2021.

Menon Sh. (2016) Choices: Inside the Making of Indian Foreign Policy, Gurgaon: Allen Lane.

Singh Z.D. (2019) Power and Diplomacy: India's Foreign Policies during the Cold War, Delhi: Oxford University Press.

Sun Y. (2020) China's Strategic Assessment of India: Commentary. War on the Rocks, March 25, 2020. Available at: https://warontherocks.com/2020/03/chinas-strategic-assessment-of-india/, accessed 10.03.2021.

Swami P. (2020) Interview: China Foreign Policy Expert Yun Sun on Border Dispute, What Went Wrong in India-China Ties, and More. Money Control, September 15, 20202. Available at: https://www.moneycontrol.com/news/ trends/current-affairs-trends/interviewchina-foreign-policy-expert-yun-sun-onborder-dispute-what-went-wrong-in-india-china-ties-and-more-5843381.html, accessed 10.03.2021.

Xiaoping Y. (2018) When India's Strategic Backyard Meets China's Strategic Periphery: The View from Beijing. War on the Rocks, April 20, 2018. Available at: https://warontherocks.com/2018/04/ when-indias-strategic-backyard-meetschinas-strategic-periphery-the-viewfrom-beijing/, accessed 10.03.2021. 


\title{
Изменение геополитики и переговорных позиций в пограничном споре между Индией и Китаем
}

\author{
Зоравар ДАУЛЕТ СИНГХ \\ кандидат наук, приглашенный научный сотрудник \\ Институт Китая, 8/17, Sri Ram Road, Civil Lines, 110054, New Delhi, India \\ E-mail: zorawar.dauletsingh@gmail.com \\ ORCID: 0000-0003-0367-5743
}

\section{ЦИТИРОВАНИЕ: Daulet Singh Z. (2021) Changing Geopolitics and Negotiating Postures in the India-China Border Dispute. Outlines of Global Transformations: Politics, Economics, Law, vol. 14, no 2, pp. 66-81. DOI: 10.23932/2542-0240-2021-14-2-4}

Статья поступила в редакцию 05.02.2021.

\begin{abstract}
АННОТАЦИЯ. Статья основана на монографии автора "Смена власти», увидевшей свет в декабре 2020 г. В работе восстановлены и проанализированы наиболее значимые события и эпизоды индийско-китайского пограничного диспута с момента первого кризиса, разразившегося в 1959 году. Автор полагает: на протяжении всей новейшей истории двусторонних отночений тидеры Китая рассматривали отношения Поднебесной с «крупнейшей демократией мира» как часть широкого геопотитического замысла, реализация которого напрямую зависела от интенсивности оказываемого на КНР давления на других «театрах» дипломатических действий. Аналогичным образом характер отношений между великими державами непосредственно влиял на формирование политики Индии в отночении Китая. «Историческая» мотивация развития двусторонних отношений сохранитась и в наши дни. В последнее десятилетие в мировой системе наметились явные сдвиги в направлении становления многостороннего баланса сил, тогда как Индия и Китай не могут расстать-
\end{abstract}

ся с прежними мотивациями в двусторонних отночениях. Двусторонние отношения остаются словно замороженными, и обе страны стремятся найти новое идеологическое равновесие, которое позволяло бы им реализовывать свои геополитические интересы и парадигмы. Однако по мере возвращения системь международных отношений в Азии к доколониальной полицентричности лидеры двух крупнейших государств мира будут вынуждены сопрягать свои внешнеполитические действия с логикой межгосударственных отношений на континенте. Подобный геополитический реализм будет способствовать стабилизаиии индийско-китайских отночений.

КЛЮЧЕВЫЕ СЛОВА: внешняя политика Индии, внешняя политика Китая, индийско-китайский пограничный спор, многополярный миропорядок, Дэн Сяопин

\section{Список литературы}

Banik A. (2020) Implications of China-US Competition in the Digital Age: 
Webinar of Dr. Yan Xuetong // Institute of Chinese Studies, September 18, 2020 // https://www.icsin.org/uploads/2020/09/ 23/c973369f98f0f1dc2e373c6e6deffof6. pdf, дата обращения 10.03.2021.

Bhasin A.S. (2018) India-China Relations 1947-2000: A Documentary Study (Vol. 4), Delhi: Geetika Publishers.

Malhotra I. (2011) The Colombo 'Compromise' // The Indian Express, October 17, $2011 / / \mathrm{https}: / /$ indianexpress.com/article/opinion/columns/the-colombo-compromise/, дата обращения 10.03.2021.

Menon Sh. (2016) Choices: Inside the Making of Indian Foreign Policy, Gurgaon: Allen Lane.

Singh Z.D. (2019) Power and Diplomacy: India's Foreign Policies during the Cold War, Delhi: Oxford University Press.

Sun Y. (2020) China's Strategic Assessment of India: Commentary // War on the Rocks, March 25, 2020 // https://waronth- erocks.com/2020/03/chinas-strategic-assessment-of-india/, дата обращения 10.03.2021.

Swami P. (2020) Interview: China Foreign Policy Expert Yun Sun on Border Dispute, What Went Wrong in India-China Ties, and More // Money Control, September 15, 20202 // https://www.moneycontrol.com/news/trends/current-affairstrends/interview-china-foreign-policyexpert-yun-sun-on-border-dispute-whatwent-wrong-in-india-china-ties-andmore-5843381.html, дата обращения 10.03.2021.

Xiaoping Y. (2018) When India's Strategic Backyard Meets China's Strategic Periphery: The View from Beijing // War on the Rocks, April 20, 2018 // https://warontherocks.com/2018/04/when-indias-strategic-backyard-meets-chinas-strategicperiphery-the-view-from-beijing/, дата обращения 10.03.2021. 